\title{
Referring Sustainable Waste Management Strategy Drives Life-Cycle Sustainable Building Benefits Of China
}

\author{
Mr. Yunhui Yang ${ }^{1, \text { a }}$, Mr. Yishan Zhao ${ }^{2, \text { b }}$ \\ Kunming Metallurgy College, Kunming, China \\ a309124927@qq.com, b 185135421@qq.com
}

Keywords: Construction Waste Management; Waste Minimization; Sustainable Building

Abstract- Construction is one of the major industries that generate wealth to China. Construction industry contribute a large of portion of solid waste stream which causes the grave negative impacts towards environment and ecosystem in China. There are increasingly serious problems that are faced by Chinese government and construction industry pertaining to waste minimization and waste management practices in construction projects nowadays. The management and appropriate use of construction waste is a good solution to the fast degradation of virgin raw materials in the construction industry of China. Hence, this paper enlightens the importance of reduce, reuse and recycle (3R) concept for managing the construction waste in China, and outlines the structure of the research for developing the framework of construction waste minimization for contractors.

\section{Introduction}

Construction and demolition waste is a worldwide issue due to the rapid growth of towns and cities, it occupies the largest share of overall waste generation in many countries with their economic growth. Development of infrastructural facilities is accompanied by construction, remodeling and demolition of buildings, roads, bridges, flyover, subways, runways, factories and other similar establishments. Construction waste occurs on account of building constructions and building renovations, and results from surplus material (excess supplies), damaged or broken material (which is thus unusable), cut-off pieces, processing waste, dismantled shuttering, used-up tools and accessories, packaging and garbage generated by the people on the construction sites. The waste generated mainly consists of inert and non-biodegradable materials such as concrete, plaster, wood, metal, broken tiles, bricks, masonry etc.

Construction and Demolition Waste Management Situation in China

As one of the major fixed asset formation sectors and cornerstone industries in the national economic system of China, the construction industry has been undergoing rapid development for the last decade. China has surpassed the USA as the world's largest municipal solid waste generator since 2004. China's annual solid waste quantities will increase by another $150 \%$ - growing from about 190,000,000 tons in 2004 to over 480,000,000 tons in 2030, more than twice the amount that will be generated in the US at the same time. Construction and demolition waste constitutes up to $50 \%$ of all solid waste in China generated from the demolition of built structures (including roads, bridges, etc.) for renovation or complete removal or renewal due to fast urbanization. However, awareness of resource-efficient construction practices is lacking in China, the excessive wastage of materials, improper management on site and low awareness of the need for waste reduction are prevalent in construction sites. 
Industrialized Countries Construction Waste and Demolition Management

In the European Union, construction waste accounts for $30 \%$ of the total waste (European Commission 2010). In the USA, construction waste constitutes $29 \%$ of the total solid waste and $35 \%$ of landfill space is taken up by construction waste. As global climatic and ecological problems have become serious, regulations such as UNFCCC (United Nations Framework Convention on Climate Change) and laws relevant to wastes in most countries have gradually reinforced. At the same time, many European countries have made considerable achievements to utilize the construction wastes in the past decades. The countries like U.K, U.S.A., France, Denmark, Germany and Japan have succeeded in developing economically feasible technologies for recycling up to $80 \%$ or $90 \%$ of construction and demolition waste. The waste recovery rate in Germany is one of the highest in the world.

Utilization of Construction and Demolition Waste in China

China still adopts conventional landfill or open storage on refuse sites for waste disposal at present, and has not attached enough importance to construction and demolition waste generation and disposal. In 2013, China generated about one billion tons of construction waste, building demolition waste accounting for about 740 million tons, while on-site construction waste accounting for about 260 million tons. Comprehensive utilization of demolition and construction waste is about 50 million tons, including recycled for concrete aggregates and other materials about 30 million tons,

and reused contents about 20 million tons. The gigantic amount of construction demolition wastes ,

due to rapid urbanization and ever-increasing population, most of the wastes, are delivered, without undergoing treatment, to suburban or rural areas for disposal by means of open storage or landfill which are the widespread practice in the majority of the cities across the nation in China today. This growing waste stream has significant impact for the society, environment and economic development. All the construction and demolition waste in most cases are considered unusable and discarded and least effort has been made for the utilization of construction waste. Thus, China's utilization level of waste only account for $5 \%$ of total construction demolition and waste.

\section{Sustainable Waste Management Strategy of Industrialized Countries}

Hierarchy of Construction and Demolition Waste Management

Integrated sustainable solid waste management strategies are usually based on the hierarchy of waste management i.e. Reduce-Reuse-Recycle-Compost-Dispose, which has been adopted by most of the industrialized countries. The hierarchy of construction and demolition waste management simply advocates that the best approach to construction and demolition waste management is to first and foremost try to reduce waste generation and separate potential recyclables at source, so as to improve the quality of materials for reuse. With respect to resource-saving and environment friendliness, a strategic hierarchy of the generalized construction and demolition waste management methods in a descending order is reduction, reusing, recycling, compost, incineration, and landfill which have been practiced worldwide for many years.

Reduction is the most efficient method to curtail waste generation and minimize waste disposal problems. Reusing refers to utilizing the waste materials in other applications and is viewed as the most desirable waste management method following reduction. Recycling means reprocessing materials into useable products. Incineration is a process that combusts organic materials and converts them into ash, flue gases, particulates, and heat, which can in turn be used to generate 
electric power. Landfill is the oldest waste management method that buries waste materials. Unfortunately, landfill, regarded as the "cheapest and easiest" to use in reality, is the most widely-used method although it is the least sustainable one widespread applied in China.

Sustainable Construction and Demolition Waste Management

A sustainable waste management plan includes considerations of more resource-friendly materials so that as renovations occur, these materials can be recycled. This can all be accomplished in a holistic way with a single waste management plan strategy. Integrated sustainable waste management is a successful concept that has evolved after years of solid waste management experience in industrialized countries. Sustainable development establishment has been evolving worldwide for almost 25 years and it is used as a measure to imbalances the ecologists in the world due to three pillars: social, economic and environment.

Sustainable Waste Management during Programming and Planning

The first phase of a closed-loop approach begins during programming and planning where the design and construction team assesses selected and specified building materials for high postconsumer recycled content, rapidly renewable materials, extracted and manufactured locally sourced materials, and if the specified excess construction materials can be diverted locally. Life-cycle conception has been applied to investigate the material flow in the sustainable construction waste management chain that involves a number of stakeholders for the project in industrialized countries. In a typical design-bid-build project, an owner asks the designer to finish the design and recruits a responsible contractor through bidding. Then the owner or the designated contractor purchases construction materials (supplied by retailers or manufacturers), which are made of raw materials extracted from natural resources by raw materials suppliers.

Other considerations may include an assessment of potentially hazardous material components during construction and occupancy, the product recyclability challenges created during the manufacturing process of building materials, as well as cost and environmental footprint created by transportation of new materials. For post-build activities in industrialized countries, a comprehensive pre-design waste management plan builds in a waste recycling process that encourages recycling behavior, making it easy for future occupants to move segregated, recyclable material horizontally and vertically in a building.

Construction and Demolition Waste Management on Construction Site

During the construction process in industrialized countries, waste is generated in various construction activities. Such waste can be separated in the forms of reusable, recyclable, recoverable materials and residue. These materials and residue are sent by haulers to contractors, recyclers, incineration plants, and landfill respectively. It is noted that most of these stakeholders that include project team, government, waste management facilities managers, and environmental waste management solution companies, take the maximum revenue as their objectives, thus the most effective policy have encouraged these stakeholders to participate in construction waste management through economic instruments.

At every construction site, contractors have an opportunity to divert a variety of construction and demolition materials, such as wood, stone, metal, cardboard, plastic, concrete, fiberboard and paneling. A contractor's waste management requirements during construction go well beyond containers and hauling of waste materials. In fact, one of the most commonly missed recycling opportunities lies with the job site trailer. Along with consideration for environmental aspects of recycling, reuse and reduction, a contractor's waste management plan for material separation, recycling, disposal and diversion must align with site safety practices to prevent contamination in 
industrialized countries.

The contractors often track disposal and recycling of waste materials about specific material diversion tonnage and the total percentage of material recycled based on volume or weight of a project's overall waste which measure and improve waste recycling performance. A waste diversion tool can also include green waste management metrics to support green certifications such as LEED in the USA, which can also set benchmarks for future projects and directly impact social behavior and understanding about sustainability. For instance, if a contractor diverts $75 \%$ of construction waste, the waste diversion tracking system translates those savings to the amount of landfill space saved, or the number of trees saved from paper recycling, or the amount of electricity saved that is now available to power homes and businesses.

\section{Construction Waste Management Instruments of Industrialized Countries}

In industrialized countries, construction waste management encompasses the collection, transporting, storage, treatment, recovery and disposal of waste, and is defined as a comprehensive, integrated and rational system approach towards achievement and maintenance of acceptable environmental quality and support of sustainable development. Waste management in construction perceived as more intricate since waste generated in almost each activity during construction process, thus, a number of management instruments are established to deal with construction waste in industrialized countries. Typical instruments are as follows:

Minimum Recycling Rate Target

Major purpose of this policy is to encourage source separation. Therefore, minimum recycling rate target is referred to as separate collection scheme. In particular, demolition projects are paid more attention due to the huge amount of waste generated and government authorities usually require threshold recycling rates for demolition projects. Industrialized countries have adopted a mandatory minimum recycling target for the construction waste including Austria, Belgium, Denmark, Finland, Germany, Slovenia, the Netherlands, the USA, and Japan.

Landfill Charging Scheme

This scheme charges construction disposed of at landfills in order to reduce the volume of construction waste. Landfill fees and wild dumping charging are commonly used for disposal construction and demolition waste control in industrialized countries. So contractors' downcycling construction and demolition waste will incur extra cost. A number of countries/regions adopted this scheme, e.g., Hong Kong, Ireland, Norway, and Denmark.

Site Waste Management Plan

Site waste management plan motivates contractors to effectively manage construction waste on sites through adequate planning, monitoring and reporting of waste, and reduce illegal transportation and disposal of construction waste. A number of countries/regions have applied this instrument, including the UK, Hong Kong, Australia, the USA, Japan, and Singapore.

Waste Facility Permit Scheme

Waste facility permit scheme limits the number and capacity of waste treatment facilities, especially for landfills and incineration facilities. Belgium implemented a restrictive permitting policy for landfills and incineration facilities to avoid the overcapacity of treatment of mixed waste.

Tax on Raw Material

Tax on Raw Material is a financial measure by shifting the price differential against raw material and in favor of secondary materials in order to reduce resource extraction, increase recycling rate, and make full use of secondary materials. This instrument is adopted in Denmark, Sweden, the UK, 
Belgium, the USA, and Italy.

Product Standard

Product standard ensures that secondary materials meet minimum quality requirements. It enlarges the secondary material market through certification of secondary materials. Submission of sorting report and obligation to sort on site under construction recycle act and establishment of standard for recycle construction waste. For example, European Standards for Aggregates were established in 2004 and a number of countries (including Austria, Belgium, Czech Republic, France, Italy, the Netherlands, Poland, Slovakia, and the UK) have mandated the adoption of these standards.

Incentives for Innovative Green Technology

Incentives such as subsidy and financial support have been provided by many government authorities of industrialized countries to promote the application of innovative green technologies for effective construction waste management. In particular, those government authorities have promoted use of green technologies through green procurement. Several positive steps have ben taken by some industrialized countries, such as compulsory requirement of waste management report for public or private construction projects, and waste management clauses of contract for contactors. The instrument is to ensure the disposal of construction waste properly. A survey conducted has revealed that waste dumped to landfills has reduced by approximately $65 \%$ while green waste management metrics and green technology scheme have been applied in those countries.

\section{Conclusion}

Since current methods and situation of waste disposal is not sustainable, managing construction and demolition waste is very vital for China in coping with future sustainable development. Through increased environmental education in schools and sustainability training on the job, the culture of Chinese construction industry can be changed to view environmental protection as a higher priority than it is now, which will gradually lead to the adoption of greener waste management practices. The Chinese government, trade organizations should host numerous training sessions specifically on construction waste management for designers, contractors. The Chinese government should also adopt for maximum prevention and reduction of waste and more environmentally friendly methods of waste disposal. Then, Chinese government should enforce stronger waste management policies or providing incentives, such as levying heavier construction waste disposal fees at landfills, and subsidizing recycling companies to increase the amount of recycling being performed. In addition, specific laws have yet to be developed to further reduce landfill of non-recycled waste.

\section{References:}

[1]Economic Instruments for Solid Waste Management: Global Review and Applications for Latin America and the Caribbean, August 2003. The Environment Division Sustainable Development Department and The Inter-American Development Bank.

[2]Fishbein, Bette K., "Building for the Future: Strategies to Reduce Construction and Demolition Waste in Municipal Projects," www.informinc.org/cdreport.html, INFORM Inc., NY June 1998.

[3]Business and Industry Recycling Venture and King County Solid Waste Division, "Contractors' Guide to Preventing Waste and Recycling-1998/99," Seattle, WA, January 1999. 
[4]China resources comprehensive utilization of the annual report of 2014 (in Chinese) , The national development and reform commission.

[5]Management of Construction and Demolition Waste; Working document no. 1; European Union: Brussels, Belgium, 2000.

[6]Begum, R. A., Satari, S. K. and Pereira, J. J., (2010). Waste Generation and Recycling: Comparison of Conventional and Industrialized Building Systems. American Journal of Environmental Sciences, 6(4), 383-388.

[7]Waste Management in China: Issues and Recommendations May 2005, Urban Development Working Papers East Asia Infrastructure Department World Bank.

[8]P. Li, "Comprehensively utilize construction waste and vigorously develop economic cycle", Practice and Theory of Sezs, vol. 06, pp. 84-91, 2007. (In Chinese).

[9]Yashuai LI, Xueqing ZHANG, Comparison and Analysis of International Construction Waste Management Policies, Construction Research Congress 2012.

[10]A brief history of landfill tax. (2011, March 21). Powerday. Retrieved from http://www.powerd ay.co.uk/news/a-brief-history-of-landfill-tax. 